\title{
PENGARUH PENGASUHAN IBU DAN NENEK TERHADAP PERKEMBANGAN KEMANDIRIAN DAN KOGNITIF ANAK USIA PRASEKOLAH
}

\author{
Eka Wulida Latifah $^{1 *}$, Diah Krisnatuti ${ }^{11}$, Herien Puspitawati ${ }^{1)}$ \\ 1Departemen IImu Keluarga dan Konsumen, Fakultas Ekologi Manusia, Institut Pertanian Bogor, Bogor 16680, \\ Indonesia \\ *) E-mail: ekawulidalatifah@gmail.com
}

\begin{abstract}
Abstrak
Penelitian ini bertujuan untuk menganalisis pengaruh karakteristik anak, ibu, dan nenek; gaya pengasuhan ibu; gaya pengasuhan nenek; kelekatan ibu-anak; dan kelekatan nenek-cucu terhadap perkembangan kemandirian dan kognitif anak. Partisipan dalam penelitian ini ialah 156 responden (52 anak usia prasekolah, 52 ibu bekerja, dan 52 nenek). Data yang digunakan dalam penelitian adalah data primer (metode wawancara dan observasi). Pengolahan dan analisis data dilakukan secara deskriptif (tabulasi silang) dan inferensia ( $t$-test, one way ANOVA dan regresi). Hasil penelitian menunjukkan bahwa ibu dan nenek menerapkan gaya pengasuhan dan kelekatan yang baik. Selain itu, anak-anak yang diasuh nenek memiliki perkembangan kemandirian dan kognitif yang baik. Pengaruh yang kuat dan signifikan terlihat pada hasil penelitian yang menunjukkan bahwa ibu yang usianya lebih muda, lama pendidikan ibu dan nenek yang semakin rendah, peningkatan gaya pengasuhan otoritatif ibu, penurunan gaya pengasuhan otoriter ibu, dan kelekatan nenek-anak yang meningkat akan memengaruhi peningkatan kemandirian anak prasekolah yang diasuh oleh nenek akibat ibu bekerja. Sementara itu, usia nenek yang lebih muda, lama pendidikan nenek yang lebih rendah, usia anak yang lebih tua ketika pertama kali diasuh nenek, dan kelekatan emosi ibu-anak dan nenek-cucu yang semakin meningkat memengaruhi secara nyata peningkatan perkembangan kognitif anak. Peran nenek ditemukan signifikan dalam penelitian ini.
\end{abstract}

Kata kunci: anak prasekolah, gaya pengasuhan, ibu-anak, kelekatan emosi, nenek-cucu

\section{The Effect of Mother and Grandmother Parenting on The Development of Autonomy and Cognitive of Preschool Children}

\begin{abstract}
This study aimed to analyze the influence of the characteristics of children, mothers, and grandmothers; maternal and grandmother parenting style; mother-child and grandmother-grandchild attachment on the development of autonomy and cognitive of preschool children. Participants in this study were 156 respondents (52 preschoolers, 52 working mothers and 52 grandmothers). The data used in this study were primary data (interview and observation method). Processing and analyzing data was done by descriptive (cross tabulation) and inferential (ttest, one way ANOVA and regression) test. The results showed that mothers and grandmothers applied good parenting and attachment. In addition, children were taken care of grandmother have good development of autonomy and cognitive. Research found that the younger mother, the lower level of education of mother and grandmother, the increase of authoritative parenting styles of mother, the decrease of parenting style of authoritarian mother, and the increase of grandmother-grandchild attachment will affect the increase of autonomy of preschool children. Meanwhile, the younger grandmother, the lower education of grandmother, the older children when they were first raised by grandmother, the increase of mother-child and grandmother-grandchild attachment influence significantly the increase of child's cognitive development. The role of the grandmother found to be significant in this study.
\end{abstract}

Keywords: preschool children, parenting style, mother-child, emotional attachment, grandmother-grandchild

\section{PENDAHULUAN}

Anak-anak usia dini merupakan aset bagi bangsa Indonesia. Sudaryanti (2012) menyatakan bahwa tingkat variabelitas kecerdasan orang dewasa, 50 persen sudah terjadi ketika masa usia dini (4 tahun pertama). Para ahli mengatakan bahwa masa usia dini disebut sebagai masa emas (golden age period), khususnya pada anak usia 0-2 tahun yang mana perkembangan otak anak mencapai angka $70-80$ persen. Usia prasekolah merupakan masa kritis dalam perkembangan siklus hidup seseorang. Menurut Erikson (1950), diacu dalam Santrock (2007), anak usia prasekolah berada pada tahap initiative vs guilt 
yang sedang berkembang ke arah industry vs inferiority. Pada tahap ini anak mengalami perkembangan yang positif dalam kreativitas, memiliki banyak ide dan imajinasi, berani mencoba, berani mengambil risiko, dan mudah bergaul. Sudaryanti (2012) menyatakan bahwa anak usia dini memiliki perkembangan fisik, motorik, intelektual, dan sosial yang sangat pesat dan menjadi landasan awal bagi tumbuh dan kembang anak. Hal ini menunjukkan betapa pentingnya masa pertumbuhan dan perkembangan anak usia dini yang tentunya membutuhkan stimulasi yang baik dari lingkungan di sekitarnya. Maka dari itu, apabila masa usia dini anak tidak diberikan pengasuhan yang baik, maka dimungkinkan akan terjadi permasalahan pada perkembangan anak di masa mendatang.

Fenomena globalisasi saat ini membebaskan para wanita untuk bekerja di luar rumah, termasuk para ibu yang memiliki anak usia prasekolah. Munculnya isu kesetaraan gender juga mengakibatkan banyak ibu yang bekerja di luar rumah baik karena tuntutan hidup maupun aktualisasi diri. Santrock (2007) menyatakan bahwa fenomena ibu yang bekerja merupakan bagian dari kehidupan modern, namun pengaruhnya masih diperdebatkan. Tingkat partisipasi angkatan kerja wanita di Jawa Barat juga cukup tinggi yakni hingga mencapai angka 41,78 persen dan mencapai angka 31,74 persen untuk wilayah Kota Bogor.

Peningkatan jumlah ibu yang bekerja tentunya mengakibatkan terjadinya perubahan struktur dan peran dalam keluarga, termasuk peran ibu dalam pengasuhan. Jenis pekerjaan yang dimiliki ibu berpengaruh negatif terhadap kualitas lingkungan pengasuhan anak (Rizkillah, Sunarti, \& Herawati, 2015). Perubahan peran ibu dari sektor domestik ke sektor publik mengakibatkan pengambilalihan peran pengasuhan dari ibu ke pengasuh lainnya. Menurut teori ekologi, anak mulai berinteraksi sosial dengan lingkungan terdekat di sekitarnya (Santrock, 2007) sehingga orang terdekat di keluarga diharapkan dapat membantu agar pengasuhan pada anak usia prasekolah yang ibunya bekerja ini bisa berlangsung optimal. Di Indonesia, fenomena pengasuhan oleh nenek menjadi pilihan bagi para ibu bekerja. Keikutsertaan nenek dalam mengasuh cucu merupakan salah satu bentuk dukungan pada keluarga ibu bekerja.

Di Negara Cina, fenomena yang mirip yang mana anak-anak ditinggalkan oleh orang tua mereka bekerja dan sebagian besar dari mereka berada dalam perawatan kakek dan neneknya (Burnette, Juanjuan, \& Fei, 2013). Pengasuhan oleh nenek dan kakek pada penduduk Cina mungkin sebagian disebabkan oleh budaya normatif sehingga peranan kakek dan nenek dalam mengasuh cucu yang merupakan hal yang biasa terjadi, sama seperti halnya di Indonesia. Pada warga Afrika Amerika, kakek dan nenek cenderung memegang peran keluarga yang penting, termasuk dalam bersama membesarkan anak dan pengambilan keputusan bersama, serta memastikan keberlangsungan hidup dan perkembangan pada keluarga. Penelitian terdahulu membuktikan bahwa pengalaman menjadi kakek dan nenek merupakan pengalaman yang kompleks dan beragam. Nenek dan kakek memiliki peran dukungan penting dalam hal emosional dan finansial untuk ibu dan anak (Viguer et al., 2010).

Pada masa awal perkembangan anak, salah satu hal penting yang harus dilakukan oleh orang tua ialah mendukung terbentuknya kelekatan yang aman pada anak (Brooks, 2001). Baird (2013) menyatakan bahwa kelekatan merupakan hal yang penting bagi pembentukan hubungan pada anak usia dini dan dapat memengaruhi hubungan anak sepanjang masa hidupnya. Byng-Hall (2002) menemukan hubungan yang erat antara kelekatan dengan jenis pengasuhan yang diberikan kepada anak. Kedua faktor ini menurutnya dapat membantu orang tua dalam menghadapi krisis yang dialami oleh anak selama masa perkembangannya.

Salah satu tujuan dalam pengasuhan menurut Brooks (2001) ialah memastikan kompetensi intelektual dan sosial anak berkembang dengan baik. Kompetensi intelektual dan sosial anak dapat dilihat pada perkembangan kognitif dan kemandirian anak yang menjadi tolak ukur yang digunakan untuk melihat kesiapan anak untuk masuk sekolah. Pada masa anak-anak, dengan kompetensi yang muncul, mereka berusaha untuk membangun rasa kontrol diri, kecukupan, dan kebanggaan dalam prestasi mereka (Santrock, 2007). Paxson dan Schady (2007) menyatakan bahwa perkembangan kognitif merupakan proses kumulatif yang komplikatif dari interpretasi suatu hubungan. Anak usia prasekolah mengembangkan kemampuan kognitif dan emosinya untuk mempersiapkan diri mereka dalam menguasai materi dan bertransisi ke tahap usia sekolah (Lleras, 2008; Santrock, 2007). Sejumlah studi menunjukkan bahwa gaya pengasuhan dan kelekatan memiliki pengaruh terhadap perkembangan kemandirian dan kognitif anak. Naupin (2012) menyatakan bahwa pengasuhan berpengaruh 
signifikan terhadap perkembangan kognitif dan sosial anak. Penelitian Saba (2002) menemukan bahwa kelekatan ibu berpengaruh terhadap kemandirian anak dan Ohba (2000) menemukan kelekatan berpengaruh terhadap perkembangan kognitif anak. Selain itu, kelekatan antara nenek dan cucu juga memengaruhi perilaku cucu (Macnab, 2004; Glass, 2010).

Mattanah (2005) menyatakan bahwa orang tua yang terlalu mendorong atau melarang serta terlalu banyak membantu anak justru akan mengakibatkan anak merasa tidak mampu atau merasa bersalah jika tidak berhasil sehingga anak menjadi tidak mandiri (Weiss, 2006). Sementara, gaya pengasuhan yang diterapkan nenek biasanya bersifat permisif (Viguer et al., 2010). Gaya pengasuhan nenek yang demikian dikhawatirkan dapat menghambat perkembangan kemandirian dan kognitif cucu yang diasuh oleh nenek. Padahal, pola pengasuhan merupakan salah satu faktor yang sangat penting dalam membangun kemandirian dan kognitif anak.

Penelitian-penelitian terdahulu lebih banyak mendalami mengenai peran pengasuhan nenek, stres dan coping nenek dalam mengasuh cucu, dan kualitas hidup nenek setelah mengasuh cucu. Penelitian yang menganalisis pengaruh pengasuhan oleh kakek/nenek terhadap perkembangan anak belum banyak dilakukan. Mengingat eratnya hubungan antara gaya pengasuhan, kelekatan, kemandirian dan kognitif anak, menjadi suatu hal yang menarik bagi peneliti untuk dapat melihat bagaimana pengaruh pengasuhan ibu dan nenek terhadap perkembangan kemandirian dan kognitif anak.

Penelitian ini bertujuan untuk mengidentifikasi karakteristik nenek, ibu bekerja, dan anak usia prasekolah; mengidentifikasi gaya pengasuhan dan kelekatan anak dengan nenek dan ibu bekerja kepada anak usia prasekolah; menganalisis perbedaan gaya pengasuhan dan kelekatan anak saat bersama nenek dan ibu bekerja kepada anak usia prasekolah; mengukur tingkat perkembangan kemandirian dan kognitif pada anak usia prasekolah; menganalisis perbedaan perkembangan kemandirian dan kognitif anak usia prasekolah berdasarkan jenis kelekatan nenek dan ibu; serta menganalisis pengaruh karakteristik anak, ibu dan nenek, gaya pengasuhan ibu, gaya pengasuhan nenek, kelekatan ibu-anak, serta kelekatan nenek-cucu terhadap perkembangan kemandirian dan kognitif anak usia prasekolah pada keluarga dengan ibu bekerja.

\section{METODE}

Penelitian ini menggunakan desain cross sectional dengan menggunakan metode survei yang dilakukan di Kecamatan Bogor Barat, Kota Bogor. Lokasi penelitian dipilih berdasarkan data Badan Pusat statistik Kota Bogor tahun 2013 yang menyebutkan bahwa Kecamatan Bogor Barat merupakan kecamatan dengan jumlah anak usia prasekolah yang cukup banyak yang merupakan urutan kedua terbanyak di Kota Bogor yakni sebanyak 15.174 orang $(21,35 \%)$.

Populasi penelitian ini adalah keluarga dengan kriteria ibu bekerja yang memiliki anak usia prasekolah dan diasuh oleh nenek di kecamatan terpilih. Contoh penelitian ini adalah keluarga yang masuk kriteria populasi penelitian dan tinggal di kelurahan terpilih. Pemilihan contoh dilakukan dengan menggunakan teknik pengambilan contoh secara sensus pada anak usia prasekolah yang diasuh oleh nenek pada tiga kelurahan dengan jumlah anak usia prasekolah terbanyak di Kecamatan Bogor Barat, yakni Kelurahan Pasir Jaya, Kelurahan Gunung Batu, dan Kelurahan Bubulak. Oleh karenanya, penelitian ini melibatkan 52 orang anak usia prasekolah, 52 ibu bekerja, dan 52 nenek yang mengasuh cucunya sehingga total partisipan dalam penelitian ini adalah 156 orang.

Data primer dalam penelitian ini terdiri atas karakteristik keluarga (usia ibu, besar keluarga, lama pendidikan ibu, jam kerja ibu, dan pendapatan per kapita); karakteristik nenek (usia nenek, lama pendidikan nenek, usia awal mengasuh cucu, frekuensi pengasuhan cucu), karakteristik anak (jenis kelamin, usia, dan status sekolah); gaya pengasuhan ibu dan nenek (otoritatif, otoriter, permisif, mengabaikan), kelekatan nenek-cucu, kelekatan ibuanak; perkembangan kemandirian dan kognitif anak usia prasekolah. Data primer diperoleh melalui observasi dan wawancara dengan alat bantu kuesioner dan Alat Permainan Edukatif (APE).

Gaya pengasuhan diukur menggunakan instrumen Parenting Styles and Dimensions Questionnaire (PSDQ) oleh Robinson et al. (1965). Instrumen ini didesain untuk mengukur aspek kedisiplinan dan kehangatan pengasuh yang terbagi menjadi 4 kategori, yakni gaya pengasuhan otoritatif, gaya pengasuhan otoriter, gaya pengasuhan permisif, dan gaya pengasuhan mengabaikan. Variabel ini terdiri atas 31 pernyataan yang terdiri atas 8 pernyataan gaya pengasuhan otoritatif, 9 
pernyataan gaya pengasuhan otoriter, 6 pernyataan gaya pengasuhan permisif, dan 8 pernyataan gaya pengasuhan mengabaikan dengan pilihan jawaban menggunakan skala Likert 1-4 meliputi 1= tidak pernah, 2= kadangkadang, 3=sering, dan 4=selalu. Reliabilitas dari kuesioner pada ibu untuk gaya pengasuhan otoritatif ialah sebesar 0,739 , gaya pengasuhan otoriter sebesar 0,625, untuk gaya pengasuhan permisif sebesar 0,371 , dan gaya pengasuhan pengabaian sebesar 0,482. Sementara itu, reliabilitas dari kuesioner pada nenek untuk gaya pengasuhan otoritatif ialah sebesar 0,682, gaya pengasuhan otoriter sebesar 0,803, untuk gaya pengasuhan permisif sebesar 0,677 , dan gaya pengasuhan pengabaian sebesar 0,531 .

Kelekatan diukur dengan menggunakan Attachment Q-Sort yang dikembangkan oleh Water dan Deane (1985) dan dimodifikasi oleh Sukardi (2011). Variabel kelekatan ini terdiri atas 30 pernyataan dengan skala Guttman meliputi keterangan $0=$ tidak dan $1=y a$. Reliabilitas kuesioner kelekatan ibu-anak adalah 0,544 dan kelekatan nenek-cucu adalah 0,411 . Perkembangan kemandirian dalam penelitian ini dikembangkan oleh peneliti dengan menggunakan konsep dari Vineland Sosial Maturity Scale yang dikembangkan oleh Doll (1965) dengan nilai Cronbach's alpha yang berbeda pada masing-masing katerori usia anak, yakni 0,768 untuk anak usia 3-4 tahun dan 0,860 untuk anak usia 4-5 tahun anak usia 5-6 tahun.

Perkembangan kognitif anak usia prasekolah diukur menggunakan Instrumen Depdiknas (2004). Instrumen Depdiknas yang digunakan dalam penelitian terdiri dari empat kelompok umur yaitu: 2,5 tahun hingga 3,4 tahun (reliabilitas 0,348 ); 3,5 tahun hingga 4.4 tahun (reliabilitas 0,711 ); 4,5 tahun hingga 5,4 tahun (reliabilitas 0,684); dan 5,5 tahun hingga 6,4 tahun (reliabilitas 0,465 ).

Pada saat melakukan pengolahan data, variabel gaya pengasuhan nenek, gaya pengasuhan ibu, kelekatan nenek-cucu, kelekatan ibu-anak, kemandirian dan kognitif anak beserta subvariabelnya diubah ke dalam bentuk rasio dengan menjumlahkan setiap jawaban hingga mendapatkan skor komposit. Setelah mendapatkan skor setiap variabel, selanjutnya skor diubah ke dalam bentuk indeks dan dikelompokkan. Skor indeks dari variabel gaya pengasuhan (ibu dan nenek), kemandirian, dan kognitif anak dikelompokkan menjadi 3 kategori yakni tinggi (indeks 80,0100,0 ), sedang (indeks 60,0-80,0) dan rendah (indeks 0,0-60,0). Sementara itu, kelekatan ibuanak dan nenek-cucu dikategorikan menjadi kelekatan aman (indeks 0,0-50,0) dan kelekatan tidak aman (indeks 51,0-100,0). Analisis data yang digunakan dalam penelitian ini meliputi analisis deskriptif dan inferensial. Untuk mengetahui hubungan antarvariabel secara deskriptif, digunakan tabulasi silang. Sementara itu, analisis inferensial yang digunakan adalah uji beda t-test, uji one way ANOVA, dan uji regresi linear berganda. Pada uji One way ANOVA dan uji regresi linear berganda, gaya pengasuhan dikelompokkan menjadi dua kategori yakni gaya pengasuhan otoritatif dan non-otoritatif (otoriter, permisif, dan mengabaikan).

\section{HASIL}

\section{Karakteristik Anak dan Keluarga}

Penelitian ini melibatkan 52 anak usia prasekolah, 52 ibu bekerja, dan 52 nenek yang mengasuh cucu. Adapun proporsi jenis kelamin anak dalam penelitian ini ialah 57,69 persen laki-laki dan 42,31 persen perempuan. Jumlah anak yang sudah sekolah dalam penelitian ini ialah sebanyak 28,85 persen. Hampir seluruh nenek $(90,38 \%)$ berada pada kategori usia dewasa madya dan hampir seluruh ibu bekerja $(98,08 \%)$ berada pada kategori usia dewasa muda (<40 tahun). Proporsi ibu yang bercerai ialah sebanyak 13,46 persen. Sekitar 30,77 persen nenek merupakan tamatan Sekolah Dasar (SD). Sebanyak 44,23 persen ibu bekerja ialah tamatan Sekolah Menengah Atas (SMA) dan 26,92 persen merupakan tamatan Perguruan Tinggi (PT). Persentase terbesar pekerjaan ibu ialah pegawai swasta $(57,69 \%)$. Persentase terbesar lama ibu bekerja berada di kisaran waktu 9 hingga 15 jam per hari $(78,85 \%)$. Keluarga ibu bekerja yang memiliki pendapatan per kapita di bawah garis kemiskinan kota Bogor (Rp360.518) hanya sebesar 9,62 persen.

\section{Karakteristik Pengasuhan Nenek}

Sebagian besar nenek dalam penelitian ini memiliki frekuensi pengasuhan sebanyak 6 hari dalam satu pekan yakni sebesar 67,31 persen. Berdasarkan hasil penelitian, sebagian besar cucu $(75,00 \%)$ dalam penelitian ini diasuh oleh nenek dengan rentang usia 0 hingga 3 bulan. Sebagian besar nenek (76,92\%) dalam penelitian ini tinggal satu rumah dengan anak dan cucunya. Sementara itu, lebih dari separuh nenek $(59,62 \%)$ dalam penelitian ini memiliki aktivitas pengasuhan yang cukup banyak dengan cucunya (6 hingga 9 kegiatan per hari). 


\section{Gaya Pengasuhan dan Kelekatan}

Menurut Baumrind (1971), gaya pengasuhan terdiri atas empat kategori yaitu authoritarian, permissive, authoritative, dan uninvolved. Ratarata skor indeks gaya pengasuhan otoritatif pada nenek ialah sebesar 68,11 dan ibu sebesar 78,29. Sebagian besar ibu bekerja dalam penelitian ini memiliki skor gaya pengasuhan otoritatif yang tinggi (76,9\%). Rata-rata skor indeks gaya pengasuhan otoriter nenek ialah sebesar 32,55 dan ibu sebesar 35,83 . Seluruh ibu bekerja $(100,0 \%)$ dan nenek $(100,0 \%)$ memiliki skor gaya pengasuhan otoriter yang rendah.

Hasil penelitian menunjukkan bahwa lebih dari separuh ibu sering menekankan anak untuk menurut kepada ibu. Rata-rata skor indeks gaya pengasuhan permisif nenek ialah sebesar 55,77 dan ibu sebesar 44,62. Sebagian besar ibu bekerja (92,3\%), lebih dari separuh nenek $(69,2 \%)$ memiliki skor gaya pengasuhan permisif yang rendah. Gaya pengasuhan permisif pada nenek dengan kategori rendah lebih banyak dibandingkan dengan ibu dan hanya nenek saja yang memiliki skor gaya pengasuhan permisif yang tinggi yakni sebanyak 5,8 persen. Rata-rata skor indeks gaya pengasuhan pengabaian nenek ialah sebesar 2,40 dan ibu bekerja 4,97. Seluruh nenek dan ibu dalam penelitian ini memiliki skor gaya pengasuhan pengabaian yang rendah.

Penelitian menemukan bahwa hampir 60,0 persen anak pada keluarga ibu bekerja memiliki kelekatan dengan nenek yang terkategori cukup aman dengan rata-rata skor indeks kelekatan sebesar 66,86 . Sebagian dari anakanak yang diasuh nenek memiliki kelekatan dengan ibu yang terkategori cukup aman dengan rata-rata skor indeks kelekatan sebesar 70,00 . Berdasarkan dimensinya, kelekatan dibagi menjadi tiga yaitu perilaku eksploratif, respon kasih sayang, dan kesadaran sosial.

Rata-rata skor indeks perilaku eksploratif, respon kasih sayang, dan kesadaran sosial anak saat bersama nenek secara berturut-turut adalah 66,$54 ; 68,08$, dan 65,96 . Rata-rata skor indeks perilaku eksploratif, respon kasih sayang, dan kesadaran sosial anak dengan ibu secara berturut-turut adalah 65,$19 ; 70,00$; dan 74,81 . Kelekatan anak saat bersama nenek terkategori cukup aman dan kelekatan anak saat bersama ibu terkategori aman sehingga hal ini menunjukkan bahwa anak memiliki perilaku eksploratif, respon kasih sayang, dan kesadaran sosial yang cukup baik saat bersama dengan ibu dan nenek (Tabel 1).
Tabel 1 Nilai rata-rata dan $p$-value gaya pengasuhan dan kelekatan anak saat bersama pengasuh

\begin{tabular}{|c|c|c|c|c|}
\hline \multicolumn{5}{|c|}{ rata } \\
\hline Variabel & $\begin{array}{l}\text { Skor } \\
\text { Nenek } \\
(n=52)\end{array}$ & $\begin{array}{c}\text { Rata-rata } \\
\text { Skor Ibu } \\
(n=52)\end{array}$ & $t$ & $p$-val \\
\hline
\end{tabular}

\begin{tabular}{|c|c|c|c|c|}
\hline \multicolumn{5}{|l|}{$\begin{array}{l}\text { Gaya } \\
\text { pengasuhan }\end{array}$} \\
\hline Otoritatif & 68,11 & 78,29 & $-3,309$ & $0,001^{*}$ \\
\hline Otoriter & 32,55 & 35,83 & $-1,003$ & 0,318 \\
\hline Permisif & 55,77 & 44,62 & 2,667 & $0,01^{* \star \star}$ \\
\hline Pengabaiar & 2,40 & 4,97 & $-2,509$ & $0,043^{*}$ \\
\hline $\begin{array}{l}\text { Kelekatan } \\
\text { dengan anak }\end{array}$ & 66,86 & 70,00 & $-0,424$ & 0,673 \\
\hline $\begin{array}{l}\text { Perilaku } \\
\text { eksploratif }\end{array}$ & 66,54 & 65,19 & $-1,249$ & 0,1 \\
\hline $\begin{array}{l}\text { Respon } \\
\text { kasih } \\
\text { sayang }\end{array}$ & 68,08 & 70,00 & 1,693 & 0,09 \\
\hline $\begin{array}{l}\text { Kesadaran } \\
\text { sosial }\end{array}$ & 65,96 & 74,81 & $-0,980$ & 0,3 \\
\hline
\end{tabular}

Hasil penelitian menemukan bahwa gaya pengasuhan dan kelekatan pengasuh berbeda signifikan antara nenek dan ibu. Rata-rata skor indeks gaya pengasuhan permisif nenek lebih tinggi dibandingkan dengan ibu. Hal ini memperlihatkan bahwa nenek lebih permisif terhadap cucu dibandingkan dengan ibu. Ratarata skor gaya pengasuhan otoritatif dan pengabaian ibu lebih tinggi dibandingkan dengan nenek. Hal ini menunjukkan bahwa ibu lebih otoritatif dan juga lebih mengabaikan dibandingkan dengan nenek. Ibu biasanya mengabaikan anak ketika merasa kelelahan, sedang sibuk, atau anak tak kunjung selesai menangis saat marah atau menginginkan sesuatu. Rata-rata skor indeks dimensi kelekatan respon kasih sayang anak saat bersama ibu lebih tinggi dibandingkan saat anak bersama nenek. Artinya, meskipun ibu bekerja namun kelekatan menunjukkan anak lebih lekat dengan ibunya dibandingkan dengan neneknya pada dimensi respon kasih sayang.

\section{Perkembangan Kemandirian dan Kognitif Anak}

Hasil penelitian menemukan lebih dari enam puluh persen anak yang diasuh oleh nenek terkategori mandiri dengan rata-rata skor indeks kemandirian adalah 90,09. Rata-rata dimensi kemandirian dalam hal self help general, self help eating, self help dressing, self direction, occupation, communication, dan locomotion anak secara berturut-turut adalah 92,$79 ; 89,19 ; 80,81 ; 88,29 ; 81,25 ; 95,85$ dan 97,09 (Tabel 2). 
Tabel 2 Sebaran kemandirian dan kognitif anak

\begin{tabular}{lc}
\hline Variabel & Indeks Skor \\
\hline Perkembangan Kemandirian & 90,09 \\
Self help general & 92,79 \\
Self help eating & 89,19 \\
Self help dressing & 80,81 \\
Self direction & 88,29 \\
Occupation & 81,25 \\
Communication & 95,85 \\
Locomotion & 97,09 \\
Perkembangan Kognitif & 74,98 \\
\hline
\end{tabular}

Sementara untuk perkembangan kognitif anak yang diasuh oleh nenek, hampir 50,0 persen berada pada kategori baik dengan rata-rata skor indeks perkembangan kognitif adalah 74,98 (Tabel 2). Anak yang diasuh oleh nenek hampir seluruhnya memiliki perkembangan kemandirian yang baik. Perkembangan kemandirian pada masing-masing kategori usia anak berbeda satu sama lain. Seluruh anak usia 3-4 tahun dan anak usia 4-5 tahun dalam penelitian ini terkategori mandiri, sedangkan sebagian besar anak berusia 5-6 tahun terkategori mandiri. Hasil penelitian juga menunjukkan bahwa sebagian besar anak usia 3-4 tahun terkategori mandiri pada aspek kemandirian umum, makan, dan mengerjakan tugas harian. Sementara itu, hampir separuh anak usia 3-4 tahun terkategori mandiri pada aspek kemandirian berpakaian dan lebih dari separuh anak usia 3-4 tahun terkategori mandiri pada aspek kemandirian untuk mengarahkan diri. Selain itu, hampir seluruh anak usia 3-4 tahun terkategori mandiri pada aspek kemandirian berkomunikasi dan bergerak.

Hasil penelitian menemukan bahwa seluruh anak usia 4-5 tahun terkategori mandiri pada aspek kemandirian umum, mengerjakan tugas harian, dan bergerak. Hasil lain juga menunjukkan bahwa lebih dari separuh anak usia 4-5 tahun terkategori mandiri dalam aspek kemandirian makan dan mengarahkan diri dan sebagian besar anak usia 4-5 tahun terkategori mandiri dalam aspek kemandirian berpakaian. Selain itu, hampir seluruh anak usia 3-4 tahun terkategori mandiri pada aspek kemandirian berkomunikasi. Penelitian menunjukkan bahwa lebih dari separuh anak usia 5-6 tahun terkategori mandiri dalam aspek kemandirian umum, berkomunikasi dan mengarahkan diri dan sebagian besarnya terkategori mandiri dalam aspek kemandirian makan dan bergerak. Hasil juga menunjukkan bahwa seluruh anak usia 5-6 tahun terkategori mandiri dalam aspek kemandirian berpakaian dan separuh anak usia 5-6 tahun terkategori mandiri dalam aspek kemandirian dalam mengerjakan tugas harian.

Analisis data juga menunjukkan bahwa sebagian besar anak usia 2,5-3,4 tahun memiliki perkembangan kognitif yang baik dan hampir separuh anak usia 3,5-4,4 tahun memiliki perkembangan kognitif yang cukup baik. Sementara itu, separuh anak usia 4,5-5,4 tahun memiliki perkembangan kognitif yang baik dan hanya terdapat satu orang anak yang memiliki usia antara 5,5-6,4 tahun yang terkategori baik.

\section{Kombinasi Kelekatan Ibu-Anak dan Nenek- Cucu Serta Kaitannya dengan Perkembang- an Kemandirian dan Kognitif Anak}

Hasil uji dengan menggunakan analisis One Way ANOVA pada Tabel 3 menunjukkan bahwa terdapat kombinasi kelekatan saat anak bersama nenek dan ibu yang menunjukkan skor kemandirian dan kognitif yang berbeda. Pada anak yang memiliki kelekatan yang aman dengan ibu dan neneknya, skor perkembangan kognitif anak menunjukkan nilai yang lebih tinggi dibandingkan anak yang hanya memiliki kelekatan yang aman dengan neneknya atau tidak lekat secara aman baik dengan nenek maupun ibunya, namun perbedaan kombinasi kelekatan ini tidak menunjukkan perbedaan yang signifikan pada skor kemandirian anak. Kombinasi gaya pengasuhan ibu dan nenek juga tidak menunjukkan perbedaan yang signifikan baik pada skor kemandirian maupun kognitif anak.

\section{Faktor yang Memengaruhi Perkembangan Kemandirian dan Kognitif Anak yang Diasuh Nenek}

Tabel 4 menunjukkan bahwa pengaruh variabel terhadap perkembangan kemandirian anak memiliki koefesien determinasi sebesar 0,266. Hasil ini mengindikasikan bahwa 26,6 persen pengaruh perkembangan kemandirian anak yang diasuh nenek pada keluarga dengan ibu bekerja dapat dijelaskan oleh perubahan variabel yang ada dalam model, sedangkan sisanya 73,4 persen dipengaruhi oleh variabel lain yang tidak ada dalam model. Hasil analisis menemukan bahwa perkembangan kemandirian anak dipengaruhi secara signifikan positif oleh jenis kelamin anak (dummy variable) dan gaya pengasuhan otoritatif ibu. 

Tabel 3 Nilai rata-rata dan $p$-value antarkombinasi kategori kelekatan dengan perkembangan kognitif pada keluarga ibu bekerja

\begin{tabular}{|c|c|c|c|c|c|}
\hline \multirow[b]{2}{*}{ No. } & \multirow{2}{*}{$\begin{array}{l}\text { Tipe kombinasi } \\
\text { kelekatan } 1\end{array}$} & \multirow{2}{*}{$\begin{array}{l}\text { Tipe kombinasi } \\
\text { kelekatan } 2\end{array}$} & \multicolumn{2}{|c|}{$\begin{array}{c}\text { Rata-rata skor indeks } \\
(0-100)\end{array}$} & \multirow[b]{2}{*}{$p$-value } \\
\hline & & & $\begin{array}{c}\text { Rata-rata } \\
\text { kelekatan } \\
1\end{array}$ & $\begin{array}{l}\text { Rata-rata } \\
\text { kelekatan } \\
2\end{array}$ & \\
\hline \multirow[t]{3}{*}{1} & Lekat dengan ibu dan nenek & Hanya lekat dengan ibu & 77,80 & 73,82 & 0,646 \\
\hline & Lekat dengan ibu dan nenek & \multirow{2}{*}{$\begin{array}{l}\text { Hanya lekat dengan nenek } \\
\text { Tidak lekat dengan ibu dan } \\
\text { nenek }\end{array}$} & 77,80 & 59,81 & $0,025^{\star *}$ \\
\hline & Lekat dengan ibu dan nenek & & 77,80 & 57,41 & $0,093^{*}$ \\
\hline \multirow{3}{*}{2} & Hanya lekat dengan ibu & Lekat dengan ibu dan nenek & 73,82 & 77,80 & 0,646 \\
\hline & Hanya lekat dengan ibu & \multirow{2}{*}{$\begin{array}{l}\text { Hanya lekat dengan nenek } \\
\text { Tidak lekat dengan ibu dan } \\
\text { nenek }\end{array}$} & 73,82 & 59,81 & 0,209 \\
\hline & Hanya lekat dengan ibu & & 73,82 & 57,41 & 0,254 \\
\hline \multirow[t]{3}{*}{3} & Hanya lekat dengan nenek & Lekat dengan ibu dan nenek & 59,81 & 77,80 & $0,025^{\star *}$ \\
\hline & Hanya lekat dengan nenek & \multirow{2}{*}{$\begin{array}{l}\text { Hanya lekat dengan ibu } \\
\text { Tidak lekat dengan ibu dan } \\
\text { nenek }\end{array}$} & 59,81 & 73,82 & 0,209 \\
\hline & Hanya lekat dengan nenek & & 59,81 & 57,41 & 0,862 \\
\hline \multirow[t]{3}{*}{4} & $\begin{array}{l}\text { Tidak lekat dengan ibu dan } \\
\text { nenek }\end{array}$ & Lekat dengan ibu dan nenek & 57,41 & 77,80 & $0,093^{*}$ \\
\hline & $\begin{array}{l}\text { Tidak lekat dengan ibu dan } \\
\text { nenek }\end{array}$ & Hanya lekat dengan ibu & 57,41 & 73,82 & 0,254 \\
\hline & $\begin{array}{l}\text { Tidak lekat dengan ibu dan } \\
\text { nenek }\end{array}$ & Hanya lekat dengan nenek & 57,41 & 59,81 & 0,862 \\
\hline
\end{tabular}

Skor kemandirian pada anak anak perempuan lebih besar dibandingkan dengan anak laki-laki, yakni sebesar 3.216 poin dan perkembangan kemandiriaan anak meningkat dengan kenaikan skor pengasuhan otoritatif ibu. Setiap kenaikan skor gaya pengasuhan otoritatif ibu akan meningkatka skor kemandirian anak sebesar 0.127 poin. Namun, kemandirian anak dipengaruhi secara signifikan negatif oleh usia ibu, lama pendidikan ibu, dan gaya pengasuhan otoriter ibu. Artinya, perkembangan kemandirian anak menurun dengan bertambahnya usia ibu, lama pendidikan ibu, dan skor pengasuhan otoriter ibu dengan nilai b berturut-turut sebesar 0.399 , 0.726 , dan 0.144

Sementara itu, model yang digunakan untuk menganalisis pengaruh variabel terhadap perkembangan kognitif anak yang diasuh oleh nenek memiliki nilai Adjusted $R$ Square sebesar 0,273 (Tabel 4). Hal ini berarti bahwa sebanyak 27,3 persen, variabel perkembangan kognitif anak dapat dijelaskan oleh perubahan variabel karakteristik anak dan ibu, gaya pengasuhan ibu, dan kelekatan ibu-anak, sedangkan sisanya 72,7 persen dijelaskan oleh variabel lain yang tidak diteliti.

Hasil uji regresi menunjukkan bahwa perkembangan kognitif anak dipengaruhi secara signifikan positif oleh kategori kelekatan ibu-anak. Skor perkembangan kognitif pada anak yang lekat secara aman dengan ibunya lebih besar sebanyak 16.667 poin dibandingkan dengan anak yang tidak lekat secara aman dengan ibunya. Akan tetapi, jenis kelamin anak (dummy variable) memiliki pengaruh signifikan negatif terhadap perkembangan kognitif anak dimana skor perkembangan kognitif pada anak laki-laki lebih besar sebanyak 7.934 dibandingkan dengan anak perempuan.

Tabel 5 menunjukkan bahwa model yang disusun untuk menganalisis pengaruh variabel nenek terhadap perkembangan kemandirian anak yang diasuh nenek memiliki nilai Adjusted $R$ Square sebesar 0,173 . Artinya bahwa model mampu menganalisis 17,3 persen pengaruh variabel nenek terhadap kemandirian anak. Sisanya, sebesar 82,7 persen dipengaruhi variabel lain yang tidak ada dalam model.

Kategori kelekatan nenek dan cucu memiliki pengaruh signifikan positif terhadap kemandirian anak. Skor perkembangan kemandirian pada anak yang lekat secara aman dengan neneknya lebih besar sebanyak 6,018 poin dibandingkan dengan anak yang tidak lekat secara aman dengan neneknya. Akan tetapi, kemandirian anak dipengaruhi secara signifikan negatif oleh lama pendidikan nenek, artinya kemandirian anak akan menurun dengan bertambahnya lama pendidikan nenek dengan nilai perubahan nilai kemandirian sebesar 2,091 poin. 
Tabel 4 Koefesien regresi untuk menganalisis pengaruh karakteristik anak, karakteristik ibu, gaya pengasuhan ibu, dan kelekatan ibu-anak terhadap perkembangan kemandirian dan kognitif anak pada anak yang diasuh nenek $(n=52)$

\begin{tabular}{|c|c|c|c|c|c|c|}
\hline \multirow{2}{*}{ Variabel } & \multicolumn{3}{|c|}{ Kemandirian } & \multicolumn{3}{|c|}{ Kognitif } \\
\hline & B & Beta & Sig. & B & Beta & Sig. \\
\hline Konstanta & 85,087 & & 0,000 & 34,847 & & 0,281 \\
\hline Usia balita (bulan) & 0,104 & 0,171 & 0,387 & $-0,417$ & $-0,209$ & 0,290 \\
\hline $\begin{array}{l}\text { Jenis kelamin } \\
(0=\text { laki-laki; } 1=\text { perempuan })\end{array}$ & 3,216 & 0,307 & $0,031^{* *}$ & $-7,934$ & $-0,231$ & $0,098^{*}$ \\
\hline $\begin{array}{l}\text { Status sekolah anak } \\
(0=\text { belum sekolah, } 1=\text { sekolah })\end{array}$ & $-2,330$ & $-0,204$ & 0,277 & 6,196 & 0,165 & 0,376 \\
\hline Usia ibu (tahun) & $-0,339$ & $-0,333$ & $0,098^{*}$ & 0,616 & 0,184 & 0,351 \\
\hline $\begin{array}{l}\text { Status pernikahan ibu }(0=\text { janda, } \\
1=\text { menikah) }\end{array}$ & 2,151 & 0,142 & 0,301 & 7,359 & 0,148 & 0,280 \\
\hline Jumlah Anak (orang) & 1,111 & 0,136 & 0,481 & $-7,043$ & $-0,263$ & 0,176 \\
\hline Lama pendidikan ibu (tahun) & $-0,726$ & $-0,455$ & $0,006^{\star * \star}$ & 0,909 & 0,173 & 0,276 \\
\hline $\begin{array}{l}\text { Pendapatan per kapita keluarga ibu } \\
\text { (rupiah) }\end{array}$ & $9,916 \mathrm{E}-7$ & 0,152 & 0,346 & $-3,249 E-8$ & $-0,002$ & 0,992 \\
\hline Gaya pengasuhan otoritatif ibu (indeks) & 0,144 & 0,427 & $0,019^{\star *}$ & 0,268 & 0,241 & 0,171 \\
\hline Gaya pengasuhan otoriter ibu (indeks) & $-0,127$ & $-0,337$ & $0,024^{\star *}$ & $-0,069$ & $-0,056$ & 0,695 \\
\hline Gaya pengasuhan permisif ibu (indeks) & $-0,106$ & $-0,190$ & 0,181 & $-0,021$ & $-0,012$ & 0,935 \\
\hline $\begin{array}{l}\text { Gaya pengasuhan mengabaikan ibu } \\
\text { (indeks) }\end{array}$ & 0,014 & 0,020 & 0,879 & $-0,260$ & $-0,116$ & 0,375 \\
\hline $\begin{array}{l}\text { Kategori gaya pengasuhan ibu }(0=\text { non } \\
\text { otoritatif, } 1=\text { otoritatif) }\end{array}$ & 3,386 & 0,153 & 0,363 & $-0,010$ & 0,000 & 0,999 \\
\hline Kelekatan aman ibu-anak (indeks) & 0,016 & 0,038 & 0,844 & 0,185 & 0,134 & 0,483 \\
\hline $\begin{array}{l}\text { Kategori kelekatan ibu-anak (0=tidak } \\
\text { aman, 1=aman) }\end{array}$ & 0,139 & 0,009 & 0,961 & 16,667 & 0,335 & $0,083^{*}$ \\
\hline $\begin{array}{l}\text { Adj. } R^{2} \\
\text { Sig. Model }\end{array}$ & & 0,0266 & & & $\begin{array}{l}0,273 \\
0,022^{* *}\end{array}$ & \\
\hline
\end{tabular}

Keterangan: ${ }^{* * *}$ signifikan pada $p \leq 0,01 ;{ }^{* *}$ signifikan pada $p \leq 0,05 ;{ }^{*}$ signifikan pada $p \leq 0,1$

Selain itu, model yang disusun untuk menganalisis pengaruh variabel nenek terhadap perkembangan kognitif anak yang diasuh nenek memiliki nilai koefesien determinasi (Adjusted $R$ Square) sebesar 0,220 (Tabel 5). Artinya, sebanyak 22 persen variabel perkembangan kognitif anak dapat dijelaskan oleh perubahan variabel bebas yang ada dalam model, sedangkan sisanya 88 persen dijelaskan oleh variabel lain yang tidak ada dalam model. Perkembangan kognitif anak dipengaruhi secara positif oleh lama pendidikan nenek, usia awal cucu saat diasuh pertama kali, dan kelekatan aman nenek-cucu. Perkembangan kognitif anak meningkat dengan bertambahnya lama pendidikan nenek, usia awal cucu saat diasuh pertama kali, dan skor kelekatan aman nenek-cucu. Sementara itu, perkembangan kognitif anak dipengaruhi secara negatif oleh usia nenek. Perkembangan kognitif anak menurun dengan bertambahnya usia nenek.

\section{PEMBAHASAN}

Perkembangan kognitif dan kemandirian pada anak yang ibunya bekerja dan diasuh oleh neneknya menunjukkan hasil yang baik. Hasil penelitian yang dilakukan oleh Hansen dan Hawsen (2009) juga menunjukkan bahwa anak yang diasuh nenek memiliki perkembangan kosakata yang baik. Almani, Abro, dan Mugheri (2012) juga menyatakan bahwa kondisi ibu bekerja tidak akan mengganggu atau menyebabkan perkembangan kognitif anak menjadi kurang baik. Skor gaya pengasuhan permisif nenek lebih tinggi dibandingkan dengan skor gaya pengasuhan permisif ibu bekerja. Hal ini selaras dengan pernyataan Viguer et al. (2010) yang mengatakan bahwa pengasuhan yang dilakukan oleh nenek dan kakek tidak terlalu ketat atau tidak terlalu disiplin. Respon kasih sayang anak dengan ibunya lebih tinggi dari neneknya. Hal ini sesuai dengan hasil penelitian Sen dan Kavlak (2012) yang menunjukkan bahwa skor kelekatan ibu lebih tinggi dibandingkan dengan skor kelekatan nenek. Hasil penelitian menunjukkan bahwa skor perkembangan kognitif anak tertinggi diperoleh pada anak yang memiliki kelekatan yang aman dengan ibu dan neneknya. Hasil penelitian menunjukkan bahwa anak perempuan lebih mandiri dibandingkan dengan anak laki-laki. Hal ini sesuai dengan hasil penelitian Meland, Kaltvedt, dan Reikerå (2015) yang mana siswa perempuan lebih mandiri dan memiliki kemampuan sosial yang lebih tinggi dibandingkan dengan siswa lakilaki. 
Tabel 5 Koefesien regresi untuk menganalisis pengaruh karakteristik nenek, gaya pengasuhan ibu, dan kelekatan nenek-cucu terhadap perkembangan kemandirian dan kognitif anak pada anak yang diasuh nenek $(n=52)$

\begin{tabular}{|c|c|c|c|c|c|c|}
\hline \multirow{2}{*}{ Variabel } & \multicolumn{3}{|c|}{ Kemandirian } & \multicolumn{2}{|c|}{ Kognitif } & \multirow[b]{2}{*}{ Sig. } \\
\hline & $B$ & Beta & Sig. & B & Beta & \\
\hline Konstanta & 85,886 & & 0,000 & 23,312 & & 0,398 \\
\hline Usia nenek (tahun) & $-0,010$ & $-0,021$ & 0,881 & $-0,491$ & $-0,308$ & $0,026^{\star *}$ \\
\hline $\begin{array}{l}\text { Lama pendidikan nenek } \\
\text { (tahun) }\end{array}$ & $-0,563$ & $-0,353$ & $0,020^{\star *}$ & 2,091 & 0,399 & $0,008^{* * *}$ \\
\hline $\begin{array}{l}\text { Usia awal cucu saat diasuh } \\
\text { pertama kali (bulan) }\end{array}$ & $-0,008$ & $-0,018$ & 0,900 & 0,458 & 0,302 & $0,035^{\star *}$ \\
\hline $\begin{array}{l}\text { Jumlah aktivitas bersama } \\
\text { cucu (aktivitas) }\end{array}$ & 0,471 & 0,142 & 0,369 & 0,558 & 0,051 & 0,738 \\
\hline $\begin{array}{l}\text { Gaya pengasuhan otoritatif } \\
\text { nenek (skor indeks) }\end{array}$ & $-0,036$ & $-0,108$ & 0,540 & $-0,188$ & $-0,174$ & 0,313 \\
\hline $\begin{array}{l}\text { Gaya pengasuhan otoriter } \\
\text { nenek (skor indeks) }\end{array}$ & 0,325 & 1,329 & 0,378 & $-0,516$ & $-0,641$ & 0,660 \\
\hline $\begin{array}{l}\text { Gaya pengasuhan permisif } \\
\text { nenek (skor indeks) }\end{array}$ & $-0,225$ & $-0,816$ & 0,596 & 0,726 & 0,800 & 0,593 \\
\hline $\begin{array}{l}\text { Gaya pengasuhan } \\
\text { mengabaikan nenek (skor } \\
\text { indeks) }\end{array}$ & $-0,126$ & $-0,113$ & 0,414 & 0,084 & 0,023 & 0,864 \\
\hline $\begin{array}{l}\text { Kategori gaya pengasuhan } \\
\text { nenek ( } 0=\text { non otoritatif, } \\
1=\text { otoritatif) }\end{array}$ & 2,018 & 0,159 & 0,418 & $-2,170$ & $-0,052$ & 0,784 \\
\hline $\begin{array}{l}\text { Kelekatan aman nenek- } \\
\text { cucu (skor indeks) }\end{array}$ & $-0,022$ & $-0,045$ & 0,800 & 0,872 & 0,537 & $0,003^{* * *}$ \\
\hline $\begin{array}{l}\text { Kategori kelekatan nenek- } \\
\text { cucu }(0=\text { tidak aman, } \\
1=\text { aman) }\end{array}$ & 6,018 & 0,372 & $0,063^{*}$ & $-12,949$ & $-0,243$ & 0,205 \\
\hline Adj, $R^{2}$ & & 173 & & & 0,220 & \\
\hline sig, Model & & $058^{*}$ & & & $0,027^{\star *}$ & \\
\hline
\end{tabular}

Keterangan: ${ }^{* * *}$ signifikan pada $p \leq 0,01 ;{ }^{* *}$ signifikan pada $p \leq 0,05 ;{ }^{*}$ signifikan pada $p \leq 0,1$

Namun, perkembangan kognitif pada anak laki-laki menunjukkan skor yang lebih tinggi dibandingkan dengan anak perempuan. Orenstein (2014) menyatakan bahwa anak laki-laki dapat menguasai informasi pada waktu yang singkat sehingga dapat memproses informasi dengan cepat. Laki-laki juga lebih dapat mengelompokkan pola bentuk dibandingkan dengan perempuan. Hasil penelitian lain juga menunjukkan hal yang serupa yang mana laki-laki memiliki kemampuan matematis yang lebih baik daripada perempuan (Maryland, 2013; Reilly, 2012).

Lama pendidikan nenek berpengaruh negatif terhadap perkembangan kemandirian anak. Hal ini dikarenakan proporsi pendidikan terbesar nenek yang terkategori rendah sehingga mengakibatkan anak menjadi tidak mandiri. Hasil penelitian menunjukkan bahwa gaya pengasuhan otoritatif ibu memiliki pengaruh yang positif terhadap kemandirian anak. Hal ini sesuai dengan pernyataan Golonka (2013) menemukan bahwa gaya pengasuhan otoritatif berpengaruh positif terhadap kemandirian anak. Sebaliknya, gaya pengasuhan otoritater ibu memiliki pengaruh yang negatif terhadap kemandirian anak. Hal ini sesuai dengan pernyataan Baumrind (1971) yang menyatakan bahwa pengasuhan yang cenderung mengekang dapat menghambat keberhasilan anak dalam mencapai perkembangan kemandirian anak.

Hasil penelitian menunjukkan bahwa anak yang lekat secara aman dengan ibunya memiliki skor perkembangan kognitif yang lebih baik dibandingkan dengan anak yang tidak lekat secara aman dengan ibunya. Hal ini diperkuat dengan hasil penelitian Saba (2002); Ruiter dan Inzerdoon (2005) yang menyatakan bahwa kelekatan memiliki pengaruh yang baik terhadap perkembangan kognitif yang baik.

Usia ibu dan lama pendidikan ibu memberikan pengaruh yang yang negatif terhadap kemandirian anak. lbu yang lebih tua memiliki anak yang lebih banyak dibandingkan dengan ibu muda sehingga anak yang paling kecil merupakan anak dengan urutan yang besar. Pada ibu yang lebih tua. anak yang tidak 
mandiri dikarenakan anak merupakan anak terkecil dalam keluarga sehingga ibu cenderung memanjakan anak dibandingkan dengan ibu muda dengan jumlah anak yang lebih sedikit. Ibu bekerja yang berpendidikan tinggi memiliki anak yang kurang mandiri dibandingkan ibu yang berpendidikan rendah. Pendidikan berkaitan dengan pekerjaan dan pendapatan tinggi. Orang tua dari kelas sosial menengah ke atas lebih memanjakan anak mereka karena memiliki sumberdaya yang lebih besar.

Usia nenek memiliki pengaruh yang negatif terhadap perkembangan kognitif anak. Hal ini menunjukkan bahwa anak yang diasuh oleh nenek yang usianya lebih tua memiliki perkembangan kognitif anak lebih rendah. Hal ini juga diduga berkaitan dengan pendidikan nenek yang rendah pada nenek yang usianya lebih tua. Lama pendidikan nenek berpengaruh positif terhadap perkembangan kognitif anak. Lleras (2008) juga menyatakan bahwa ibu dengan status pendidikan yang tinggi mungkin akan lebih mementingkan pendidikan dan memiliki keahlian yang dibutuhkan untuk meningkatkan kemampuan kognitif anak. Pada ibu yang bekerja, posisi nenek menggantikan ibu selaku pengasuh utama sehingga nenek yang lebih tua memiliki pendidikan yang rendah dan mengakibatkan perkembangan kognitif anak menjadi rendah. Nenek yang memiliki pendidikan yang tinggi dapat membantu meningkatkan perkembangan kognitif anak.

Hasil penelitian yang menunjukkan bahwa usia awal saat anak diasuh nenek pertama kali memiliki pengaruh terhadap perkembangan kognitif anak dimana anak yang dititipkan pada usia yang lebih tua memiliki perkembangan kognitif yang lebih baik. Hal senada diungkapkan oleh Ruhm (2000) dan Walfdogel et al. (2002) yang menyatakan bahwa perkembangan kognitif pada anak yang ibunya bekerja menunjukkan hasil yang lebih rendah pada usia yang lebih muda.

Anak yang memiliki kelekatan yang aman dengan neneknya memiliki skor perkembangan kemandirian yang lebih tinggi dibandingkan anak yang tidak lekat secara aman dengan neneknya. Ohba (2000) menyatakan bahwa kelekatan yang baik akan mendukung perkembangan kemandirian anak yang baik. Hasil penelitian lain juga menunjukkan bahwa kelekatan memiliki kaitan yang erat dengan kemandirian (Brenning, Soenens, \& Braet, 2012; Lynch, 2013). Hasil penelitian juga menunjukkan bahwa kelekatan anak saat bersama dengan nenek memiliki dampak yang positif terhadap perkembangan kognitif anak. Egeland et al. (1993) dan Malekpour (2007) menyatakan bahwa kelekatan memiliki pengaruh terhadap perkembangan kognitif anak. Hal ini serupa dengan hasil penelitian Schultz (1976) yang menyatakan bahwa kelekatan yang baik antara nenek dan cucu berhubungan dengan perkembangan kognitif cucu yang semakin baik.

\section{SIMPULAN DAN SARAN}

Ibu bekerja dan nenek menerapkan gaya pengasuhan otoritatif dengan cukup baik, namun ibu dan nenek terlihat masih menerapkan gaya pengasuhan yang cukup otoriter dan permisif. Penerapan gaya pengasuhan yang permisif pada nenek lebih terlihat dibandingkan dengan ibu. Kelekatan yang terjalin pada anak saat bersama dengan nenek maupun dengan ibunya memiliki tingkat yang cukup aman. Meskipun secara fisik ibu tidak berada di dekat anak, ternyata anak memiliki respon kasih sayang yang lebih baik saat bersama dengan ibunya sehingga ibu tidak perlu khawatir anak menjadi lebih lekat kepada nenek dibandingkan dengan ibu. Perkembangan kognitif dan kemandirian pada anak yang ibunya bekerja dan diasuh oleh neneknya menunjukkan hasil yang baik.

Anak yang memiliki kelekatan yang aman secara bersamaan dengan ibu dan neneknya memiliki skor perkembangan kognitif yang lebih baik. Anak perempuan memiliki kelebihan dalam kemandirian, sementara anak laki-laki memiliki kelebihan dalam perkembangan kognitif. Usia ibu, lama pendidikan ibu, gaya pengasuhan ibu, dan lama pendidikan nenek memiliki pengaruh terhadap kemandirian anak. Kelekatan ibuanak, usia nenek, lama pendidikan nenek, usia awal saat cucu diasuh pertama kali, dan kelekatan nenek-cucu memengaruhi perkembangan kognitif anak.

Untuk dapat mendukung perkembangan kemandirian yang baik, ibu perlu menerapkan gaya pengasuhan yang otoritatif. Perkembangan kemandirian dan kognitif anak dapat ditingkatkan oleh nenek dan ibu dengan cara menjalin kelekatan yang aman saat mengasuh anak. Penyediaan alat permainan edukatif membantu nenek untuk dapat menstimulasi perkembangan kognitif anak karena aktivitas nenek sudah cukup disibukkan dengan mengasuh cucu dan mengerjakan pekerjaan rumah tangga lainnya. 


\section{DAFTAR PUSTAKA}

Almani, A. S., Abro, A., \& Mugheri, R. A. (2012). Study of the effect of working mothers on development of children in pakistan. International Journal of Humanities and Social Science, 2(11).

Baird, N.C. (2013). Attachment experiences of grandparent kinship caregivers and nonkinship foster parents with preschool-aged children in their care. (Disertasi). The University of Utah.

Baumrind, D. (1971). Current patterns of parental authority. Journal of Developmental Psychology, 4(1), 1-103. Diambil dari http://www.proquest.com.

Brenning. (2012). The role of parenting and mother-adolescent attachment in the intergenerational similarity of internalizing symptoms. Journal of Youth Adolescence, 41, 802-816. doi:10.1007/ s10964-011-9740-9.

Brooks, J. B. (2001). Parenting third edition. Mountain View: Mayfield Publishing Company.

Byng-Hall, J. (2002). Relieving parentified children's burdens in families with insecure attachment patterns. Family Process, Fall 2002, pg 375.

[Depdiknas] Departemen Pendidikan Nasional. (2004). Instrumen penelitian kompetensi perkembangan anak usia 3,5-6,4 tahun. Jakarta, ID: Pusat Kurikulum Pengembangan Departemen Pendidikan Nasional.

Burnette, D. Juanjuan S., Fei, S. (2013). A comparative review of grandparent care of children in the U.S. and China. Ageing Int, 38, 43-57. doi:10.1007/s12126-0129174-z

Doll, E. (1965). Vineland sosial maturity scale. Minnesota: Amerika Guidance Service. Inc.

Egeland, B., Carlson, E., \& Sroufe, L. A. (1993). Resilience as process. Development and Psychopathology, 5, 517-528.

Glass, L. M. (2010). Grandparent-grandchild attachment and psychosocial adjustment among youth from divorced families. (Disertasi). Sam Houston State University

Golonka, M. M. (2013). Keeping in touch: relationships between parenting style, parent-child electronic communication, and the developing autonomy and adjustment of college students. (Disertasi). Duke University

Hansen, K., \& Hawsen, D. (2009). Early childcare and child development. Jnl Soc. Pol., 38(2), 211-239.

Lleras, C. (2008). Employment, work conditions, and the home environment in single-mother families. Journal of Family Issues. doi: 10.1177/0192513X08318842.

Lynch, M.F. (2013). Attachment, autonomy, and emotional reliance : a multilevel model. Journal of conceling and development, Jul 2013, 91,3, pg 301

Macnab, M. L. D. (2004). Grandchild adjustment and family functioning in grandparent-headed families : the role of attachment relationships (Thesis). Purdue University.

Malekpour, M. (2007). Effect of attachment on early a development. The British of Development Disabilities, 105(53).

Maryland. (2013). Child and adolescent cognitive performance: gender gaps and the influences of social cohesion and socio-emotional skills on cohorts in Andhra Pradesh, India. (Disertasi). Johns Hopkins University.

Mattanah, J. F. (2005). Authoritative parenting and the encouragement of autonomy. The family context of parenting in children's adaptation to elementary school. Monographs in parenting series. (pp. 119-138). Mahwah, NJ: Lawrence Erlbaum Associates. Diambil dari http:// www.proquest.com

Meland, A. T., Kaltvedt, E. H., \& Reikerås, E. (2015). Toddlers master everyday activities in kindergarten: a gender perspective. European Early Childhood Education Research Journal. Diambil dari http://www.proquest.com.

Naupin, A. M. (2012). The influence of parenting on cognitive and socialemotional development associated with preterm birth: A multiple-group comparison using structural equation modeling. (Disertasi). Michigan State University

Ohba, C. (2000). The contribution of parents' internal working model of attachment relationship and parenting quality to toddler' autonomy (Disertasi). The University of Texas, Austin. 
Orenstein, O. (2014). The relationships between sex. poverty. and maternal education to cognitive development (Thesis). University of Nevada, Reno

Paxson, C., \& Schady, N. (2007). Cognitive development among young children in ecuador: the roles of wealth, health, and parenting. Journal of Human Resources, 42(1), 49-84.

Reilly, D. (2012). Gender, culture, and sextyped cognitive abilities. PLOS ONE, 7(7). doi:10.1371/ journal.pone.0039904

Rizkillah, R., Sunarti, E., \& Herawati, T. (2015). Kualitas perkawinan dan lingkungan pengasuhan pada keluarga dengan suami-istri bekerja. Jur. IIm. Kel. \& Kons., 8(1), 10-19.

Robinson, C. C., Mandleco, B., Olsen, S. F., \& Hart, C. H. (1995). Authoritative, authoritarian, and permissive parenting practices: Development of a new measure. Psychological Reports, 77, 819-830.

Ruhm, C. (2000). Parental employment and child cognitive development. NBER Working Paper Series. April 2000.

Ruiter, C. D., \& Inzerdoorn, M. H. V. (2005). Attachment and cognition: A review of the literature (Disertasi). University of Amsterdam dan Leiden University.

Saba, J. F. (2002). Quality of mothers' engagement with their toddlers: the roles of maternal social support, empathy, and childrearing history (Disertasi). New York, US: The Steinhardt School of Education, New York University. Diambil dari http:// www.proquest.com.

Santrock, J. W. (2007). Perkembangan anak. Terjemahan Mila rahmawati. Anna Kuswanti. Jakarta, ID: Erlangga.

Schultz. (1976). A cognitive-developmental study of the grandchild-grandparent bond. (Disertasi). Michigan : The Ohio State University. Diambil dari http:// www.proquest.com.

Sen, S., \& Kavlak, O. (2012). Transgenerational attachment in Manisa, Turkey. Contemporary Nurse, 41(1), 126-132. April 2012.

Sudaryanti. (2012). Pentingnya pendidikan karakter bagi anak usia dini. Jurnal Pendidikan Anak, 1(1), Juni 2012.

Sukardi, A. N. (2011). Kajian riwayat perkembangan anak, sensitivitas, dan kelekatan ibu terhadap anak usia 3-5 tahun di kampung adat urug kabupaten bogor (Skripsi). Bogor, ID: Fakultas ekologi manusia, Institut Pertanian Bogor.

Viguer, P., Melendez, J. C., Valencia, S., Cantero, Ma․ J., \& Navarro, E. (2010). Grandparent-grandchild relationships from the children's perspective: Shared activities and socialization styles. The Spanish Journal of Psychology, 13(2), 708-717. Diambil dari http://www.ucm.es/ info/psi/.

Walfdogel, J., Han, W. J., \& Jeanne, B. G. (2002). The effects of early maternal employment on child cognitive development. Demography (pre2011),39(2), May 2002.

Water, E., \& Deane. K. (1985). Defining and assessing individual differences in attachment relationships: Qmethodology and the organization of behavior in infancy and early childhood. In I. Bretherton \& E. Waters (Eds.). Monographs of the Society for Research in Child Development, 50(1-2), 41-65.

Weiss, D. E. (2001). Mothers' and fathers' judgments about young girls' and boys' autonomy (Disertasi). University of California, Berkeley. Diambil dari http://www.proquest.com. 